\title{
Styloid Process Elongation or Eagle's Syndrome: Is There Any Role for Ectopic Calcification?
}

\author{
Cumali Gokce \\ Yildiray Sisman ${ }^{\mathrm{b}}$ \\ Murat Sipahiogluc
}

\begin{abstract}
The styloid process (SP) is a cylindrical, long cartilaginous bone located on the temporal bone. The normal SP length is approximately $20-30 \mathrm{~mm}$. The styloid process elongation (SPE) can be assumed if either the SP or the adjacent stylohyoid ligament ossification shows an overall length in excess of $30 \mathrm{~mm}$. Elongated SP is known as Eagle's syndrome when it causes clinical symptoms as neck and cervicofacial pain. It is supposed that this symptoms and signs are due to the compression of the SP on some neural and vascular structures. It may also cause stroke due to the compression of carotid arteries. This syndrome is diagnosed by both radiographical and physical examination. Instead of many hypotheses and studies, the exact etiology of elongated SP and the role of ectopic calcification are unknown. Ectopic calcification (EC) might have a role for the elongation of SP. Abnormal calcium (Ca), phosphorus (P) and vitamin D metabolism is very common in patients with end-stage renal disease (ESRD). Therefore, this calcification in nonosseous soft tissue due to abnormal serum $\mathrm{Ca}$ and $\mathrm{P}$ levels is commonly associated with this disorder. EC due to the abnormality in this metabolism which is related to the duration of dialysis is also very important for this calcification. Therefore, a study in patients with ESRD investigating the prevalence of SP and the correlation between dialysis period and the SP length may help us explaining the role of EC in the elongation of SP. Because, this disease might be a good model for the investigation of the EC in this elongation. However, further studies and large samples are also needed to clarify the etiology of this disorder. (Eur J Dent $2008 ; 2: 224-228$ ]
\end{abstract}

Key words: Eagle's Syndrome; Ectopic calcification; End-stage renal disease; Panoramic radiography.

[- a Dr., Department of Endocrinology and Metabolism, Kayseri Training and Research Hospital,

Kayseri, Turkey.

b Assistant Professor, Department of Oral Diagnosis and Radiology, Faculty of Dentistry, Erciyes University, Kayseri, Turkey.

c Assistant Professor, Department of Internal Diseases, Faculty of Medicine, Erciyes University,

Kayseri, Turkey.

- Corresponding author: Dr. Yildiray Sisman Department of Oral Diagnosis and Radiology, Faculty of Dentistry, Erciyes University, 38039, Melikgazi, Kayseri, Turkey.

Phone: +903524374901/29226

Fax: +903524380657

E-mail: drsismanđyahoo.com

\section{INTRODUCTION}

The styloid process (SP) is a cylindrical, long cartilaginous bone located on the temporal bone. The muscles and ligaments which have a role in mastication and swallowing are attached to the SP. There are many nerves and vessels such as carotid arteries adjacent to the SP. The SP and the stylohyoid ligament develop from the Reichert's cartilage (second pharyngeal arch). ${ }^{1-7}$ The normal SP length is approximately 20-30 $\mathrm{mm}$. $^{3,4,8-13}$ The styloid process elongation (SPE) can be assumed if either the SP or the adjacent stylohyoid ligament ossification shows an overall 
length in excess of $30 \mathrm{~mm}^{1,3,4,8,10,12-17}$ (Figure 1). The reported radiographic prevalence of the SPE varies in the literature (2-30\%).3,10,13,16,18-20

The elongated SP and structural changes in stylohyoid ligament with its clinical symptoms were first described by Eagle. ${ }^{21,22}$ Elongated SP is known as Eagle's syndrome when it causes clinical symptoms as neck and cervicofacial pain. ${ }^{1,2,5,10,11,17,21,23,24}$ It is supposed that this symptoms and signs are due to the compression of the SP on some neural and vascular structures. More uncommonly, symptoms such as dysphagia, tinnitus, and otalgia may occur in patients with this syndrome. ${ }^{1,2,5,25}$ It may also cause stroke due to the compression of carotid arteries. 1,8,26 The compression depends on the size, shape, and orientation of the ossified SP. ${ }^{27}$ Besides, degenerative or inflammatory changes in the tendinous portion of the styloid ligament insertion or rheumatic styloiditis may also cause this syndrome. ${ }^{8}$ The symptoms due to this syndrome can be confused with some disorders including a wide variety of facial neuralgias, oral, dental and, temporomandibular diseases. Therefore, a detailed differential diagnosis for SPE should be done. ${ }^{24}$

Eagle's syndrome is diagnosed by both radiographical and physical examination. The SP palpation in the tonsillar fossa is indicative of SPE which are not normally palpable. Palpation of the tip of the SP should exacerbate existing symptoms. If highly suspicious for Eagle's syndrome, confirmation can be done by radiographical imaging. ${ }^{28}$ More commonly; a panoramic radiography (PR) is used to determine whether the SP is elongated. Panoramic images are most useful clinically for diagnosing disorders related to facial structures including maxillary and mandibular bones and their supporting structures.3,4,9-12,29-33 Although PRs have an important role for demonstrating the variations of SP, they are not able to show the orientation and dimensions of this bone. On the other hand, multislice computed tomography (MSCT) provides a reliable visualization of this features. ${ }^{17,27,34}$ However, many reports have shown that SPE was not the only reason of the symptoms and signs, and they suggested that other factors such as mediolateral angling (MLA), anteroposterior angling (APA) and the bending of the SP head were also important. ${ }^{27,34,35}$ Therefore, radiographic imaging may be enough for the patients with Eagle's syndrome who has normal bone structure. But, if there is any complication regarding this bone like tumor, ${ }^{36}$ osteomyelitis ${ }^{37}$ or fracture, ${ }^{38}$ this complication could be easily detected by bone scintigraphy due to the high sensitivity of this imaging method. ${ }^{35}$

The exact cause of the elongated SP due to calcified and ossified bone and ligament is not clear. It was suggested that local chronic irritations, surgical trauma, endocrine disorders in female at menopause, persistence of mesenchymal elements, growth of the osseous tissue and mechanical stress or trauma during development of SP could result in calcified

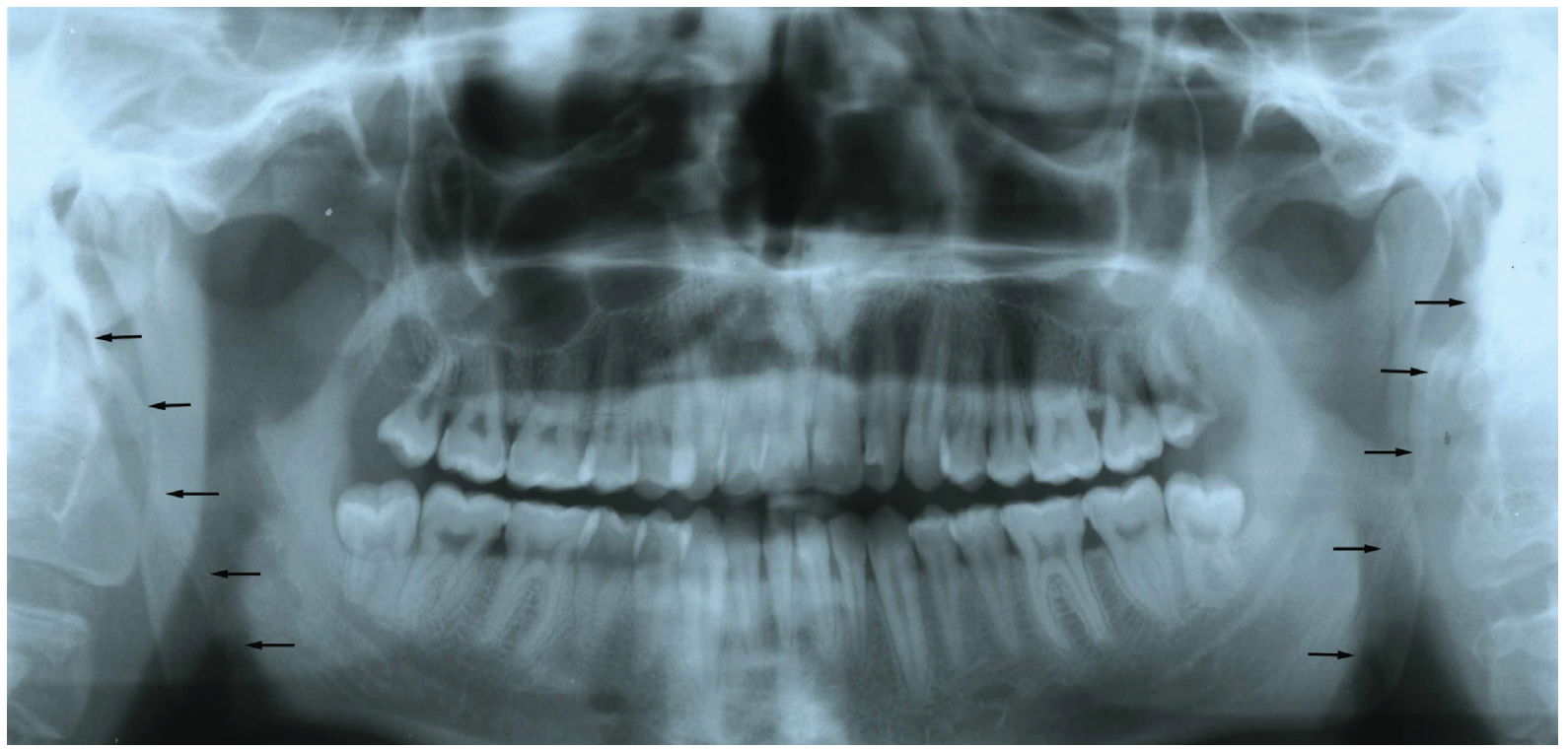

Figure 1. Bileteral styloid process elongation in a subject on a panoramic radiography. 
hyperplasia of the SP. ${ }^{6,8,17,39,40}$ In a study, Okabe et $\mathrm{al}^{33}$ found a significant correlation between the serum calcium ( $\mathrm{Ca}$ ) concentration and the SP length among 80-year-old subjects. The longer the SP was, the higher the serum $\mathrm{Ca}$ concentration was in this sample. They also evaluated the correlation between the SP length and heel bone density in these subjects. It was found that the longer the SP was, the higher the heel bone density was. However, there is no more study investigating the role of $\mathrm{Ca}$ and phosphorus (P) metabolism (ectopic calcification) in terms of SPE in the literature.

\section{IS THERE ANY ROLE FOR ECTOPIC CALCIFICATION?}

Extraskeletal (ectopic) calcification (deposition calcium phosphate crystals) or ossification (true bone formation) might have a role for the elongation of SP. Ectopic calcification (EC) in nonosseous soft tissue may be due to three mechanisms; metastatic calcification due to disorders causing abnormal serum $\mathrm{Ca}$ and $\mathrm{P}$ levels, dystrophic calcification due to mineral deposition into metabolically impaired or dead tissue despite normal serum levels of $\mathrm{Ca}$ and $P$, and ectopic ossification. In patients with endstage renal disease (ESRD) have risks for EC or ossification due to disorders (renal failure, dialysis, secondary hyperparathyroidism) causing metastatic calcification. ${ }^{41}$

Abnormal $\mathrm{Ca}, \mathrm{P}$ and vitamin $\mathrm{D}$ metabolism is very common in patients with ESRD. ${ }^{41-44}$ Disturbances in this metabolism in these patients causes prolonged stimulation of parathyroid glands. This results in increased synthesis and release of parathyroid hormone (PTH). Therefore, it causes parathyroid hyperplasia-secondary hyperparathyroidism (SHPT). SHPT causes skeletal disturbance that characterizes renal osteodystrophy. It is associated with vascular and other soft tissue calcifications. ${ }^{43-49}$ Moreover, high PTH levels, an increased hyperphosphatemia and calcium $X$ phosphate product are associated with increased mortality rate in patients with ESRD. ${ }^{46}$ Therefore, therapeutic regimens that can maintain normal serum $\mathrm{Ca}$ and $\mathrm{P}$ levels, reduce PTH secretion, and correct deficiency of 1a,25dihydroxycholecalciferol in these patients. ${ }^{42-}$ $44,47,48,50,51$
EC-metastatic calcification- in nonosseous soft tissue due to abnormal serum $\mathrm{Ca}$ and $\mathrm{P}$ levels (abnormality in $\mathrm{Ca}$ and $\mathrm{P}$ metabolism) is very common in patients with ESRD. ${ }^{41}$ Therefore, this disease may be a good model for the investigation of the EC in the elongation of SP. However, a detailed differential diagnosis should be done for this disorder. Therefore, the ESRD patients had co-disorders causing dystrophic calcification (scleroderma, dermatomyositis, and systemic lupus erythematosis, trauma-induced) and ectopic ossification (post surgery, burns, neurological injury, myositis ossificans) should be eliminated. The extent of EC increases with the dialysis period and age. ${ }^{52} \mathrm{EC}$ due to the abnormality in $\mathrm{Ca}$ and $\mathrm{P}$ metabolism which is related to the duration of dialysis is also very important for this calcification in these patients. ${ }^{41,52}$

\section{CONCLUSIONS}

As a result, SPEs found as incidental findings on PRs may be important clinically in not only normal population, but also in patients with systemic disorders such as ESRD. Instead of many hypotheses and studies, the exact etiology of elongated SP and the role of EC are unknown. To our knowledge, there is no study investigating the role of $\mathrm{Ca}$ and $\mathrm{P}$ metabolism in terms of $\mathrm{EC}$ in the elongation of the SPE. Therefore, a study in patients with ESRD investigating the prevalence of SP and the correlation between dialysis period and SP length may help us explaining the role of EC in the elongation of SP. However, further studies and large samples are also needed to clarify the etiology of this disorder.

\section{REFERENCES}

1. Carter L. Soft tissue calcification and ossification. In: White SC, Pharoah MJ, eds. Oral radiology, principles and interpretation. Missouri: Mosby, 2004: 597-614.

2. Neville BW, Damm DD, Allen CM, Bouquot JE. Developmental defects of the oral and maxillofacial region. In: Neville BW, Damm DD, Allen CM, Bouquot JE, eds. Oral and maxillofacial pathology. Philadelphia: W.B. Saunders company, 1996:1-43.

3. Gokce C, Sisman Y, Tarim Ertas E, Akgunlu F, Ozturk A. Prevalence of styloid process elongation on panoramic radiography in the Turkey population from Cappodocia region. Eur J Dent 2008;2:18-22. 
4. Sisman Y, Gokce C, Sipahioglu M, Tarim Ertas E, Oymak O, Utas C. Bilateral elongated styloid process in an end-stage renal disease patient with peritoneal dialysis: is there any role for ectopic calcification? Eur J Dent 2008; (In press).

5. Gözil R, Yener N, Calgüner E, Araç M, Tunç E, Bahcelioḡlu M. Morphological characteristics of styloid process evaluated by computerized axial tomography. Ann Anat 2001;183:527535.

6. Krennmair G, Piehslinger E. Variants of ossification in the stylohyoid chain. Cranio 2003;21:31-37.

7. Camarda AJ, Deschamps C, Forest D. II. Stylohyoid chain ossification: a discussion of etiology. Oral Surg Oral Med Oral Pathol 1989;67:515-520.

8. Prasad KC, Kamath MP, Reddy KJ, Raju K, Agarwal S. Elongated styloid process (Eagle's syndrome): a clinical study. J Oral Maxillofac Surg 2002;60:171-175.

9. Monsour PA, Young WG: Variability of the styloid process and stylohyoid ligament in panoramic radiographs. Oral Surg Oral Med Oral Pathol 1986;61:522-526.

10. Ilgüy M, Ilgüy D, Güler N, Bayirli G. Incidence of the type and calcification patterns in patients with elongated styloid process. J Int Med Res 2005;33:96-102.

11. Kursoglu P, Unalan F, Erdem T. Radiological evaluation of the styloid process in young adults resident in Turkey's Yeditepe University faculty of dentistry. Oral Surg Oral Med Oral Pathol Oral Radiol Oral Endod 2005;100:491-494.

12. Jung $T$, Tschernitschek $H$, Hippen $H$, Schneider B, Borchers

L. Elongated styloid process: when is it really elongated? Dentomaxillofac Radiol 2004;33:119-124.

13. Zaki HS, Greco CM, Rudy TE, Kubinski JA. Elongated styloid process in a temporomandibular disorder sample: prevalence and treatment outcome. $J$ Prosthet Dent 1996;75:399-405.

14. Ferreira de Albuquerque R Jr, Muller K, Hotta TH, Goncalves M. Temporomandibular disorder or Eagle's syndrome? A clinical report. J Prosthet Dent 2003;90:317-320.

15. Lee S, Hillel A. Three-dimensional computed tomography imaging of Eagle's syndrome. Am J Otolaryngol 2004;25:109.

16. Keur JJ, Campbell JP, McCarthy JF. The clinical significance of the elongated styloid process. Oral Surg Oral Med Oral Pathol 1986;61:399-404.

17. Murtagh RD, Caracciolo JT, Fernandez G. CT findings associated with Eagle syndrome. Am $J$ Neuroradiol 2001;22:1401-1402.

18. Bozkir MG, Boga $H$, Dere F. The evaluation of elongated styloid process in panoramic radiographs in edentulous patients. Tr J Medical Science 1999;29:481-485.

19. Grossman JR, Tarsitano JJ. The styloid-stylohyoid syndrome. J Oral Surg 1977;35:555-560.

20. Erol B. Radiological assessment of elongated styloid process and ossified stylohyoid ligament. Journal of Marmara University Dental Faculty 1996;2:554-556.

21. Eagle WW. Elongated styloid process. Report of two cases. Arch Otolaryngol 1937;25:548-587.

22. Eagle WW. Elongated styloid process, further observations and a new syndrome. Arch Otolaryngol 1948;47:630-640.

23. Cernea CR, Hojaij FC, De Carlucci D Jr, et al. First-bite syndrome after resection of the styloid process. Laryngoscope 2007;117:181-182

24. Aral IL, Karaca I, Güngör N. Eagle's syndrome masquerading as pain of dental origin. Case report. Aust Dent J 1997;42:1819.

25. Bafaqeeh SA. Eagle syndrome: classic and carotid artery types. J Otolaryngol 2000;29:88-94.

26. Chuang WC, Short JH, McKinney AM, Anker L, Knoll B, McKinney ZJ. Reversible left hemispheric ischemia secondary to carotid compression in Eagle syndrome: surgical and CT angiographic correlation. Am J Neuroradiol 2007;28:143-145.

27. Ramadan SU, Gokharman D, Tuncbilek I, Kacar M, Kosar P, Kosar U. Assessment of the stylohoid chain by 3D-CT. Surg Radiol Anat 2007;29:583-588.

28. Rechtweg JS, Wax MK. Eagle's syndrome: a review. Am J Otolaryngol 1998;19:316-321.

29. Lurie AG. Panoramic imaging. In: White SC, Pharoah MJ, eds. Oral radiology, principles and interpretation. Missouri: Mosby, 2004:191-209.

30. Sisman Y, Tarim Ertas E, Gokce C, Menku A, Ulker M, Akgunlu $F$. The prevalence of carotid artery calcification on the panoramic radiographs in Cappadocia region population. Eur J Dent 2007;1:132-138.

31. Gokce C, Sisman Y, Sipahioglu M, et al. The prevalence of carotid artery calcification on the panoramic radiographs of end-stage renal disease patients with peritoneal dialysis: do incidental findings provide life-saving information? J Int Med Res 2008;36:47-53.

32. Sisman Y, Uysal T, Gelgor IE. Hypodontia. Does the prevalence and distribution pattern differ in orthodontic patients? Eur J Dent 2007;1:167-173.

33. Okabe S, Morimoto Y, Ansai T, et al. Clinical significance and variation of the advanced calcified stylohyoid complex detected by panoramic radiographs among 80 -year-old subjects. Dentomaxillofac Radiol 2006;35:191-199.

34. Bașekim CC, Mutlu H, Güngör A, et al. Evaluation of styloid process by three dimensional computed tomography. Eur Radiol 2005;15:134-139.

35. Onbas 0, Kantarci M, Murat Karasen R, et al. Angulation, length, and morphology of the styloid process o the temporal bone analyzed by multidetector computed tomography. Acta Radiol 2005;46:881-886. 
36. Mirza N, Crumley R. Facial paralysis in a benign osseous parotid tumor: a case report. Otolaryngol Head Neck Surg 1993;108:367-371.

37. Elgazzar HA, Silberstein EB. Skeletal scintigraphy in nonneoplastic osseous disorders. In: Henkin RE, Bova D, Dillehay GL, et al., eds. Nuclear medicine. Philadelhia, Pennsylvania: Mosby Elsevier Inc., 2006:1121-1181.

38. Atsu SS, Tekdemir I, Elhan A. The coexistence of temporomandibular disorders and styloid process fracture: a clinical report. Prosthet Dent 2006;95:417-420.

39. Balbuena L Jr, Hayes D, Ramirez SG, Johnson R. Eagle's syndrome (elongated styloid process). South Med J 1997;90:331-334.

40. Fini G, Gasparini G, Filippini F, Becelli R, Marcotullio D. The long styloid process syndrome or Eagle's syndrome. $J$ Craniomaxillofac Surg 2000;28:123-127.

41. Favus MJ, Vokes TJ. Paget disease and other dysplasias of bone. In: Jameson JL, ed. Harrison's endocrinology. USA: McGraw-Hill Companies, 2006:485-498.

42. Luke RG. Chronic renal failure. In: Goldman L, Ausiello D, eds. Cecil textbook of medicine. Philadelphia, Pennsylvania: Saunders, 2004:708-716.

43. Slatopolsky E. The role of calcium, phosphorus and vitamin $D$ metabolism in the development of secondary hyperparathyroidism. Nephrol Dial Transplant 1998;13:3-8.

44. Hruska KA, Teitelbaum SL. Renal osteodystrophy. $N$ Engl J Med 1995;333:166-174.

45. Cunningham J. Achieving therapeutic targets in the treatment of secondary hyperparathyroidism. Nephrol Dial Transplant 2004;19(Suppl. 5):V9-14.

46. Locatelli F, Cannata-Andía JB, Drüeke TB, et al. Management of disturbances of calcium and phosphate metabolism in chronic renal insufficiency, with emphasis on the control of hyperphosphataemia. Nephrol Dial Transplant 2002;17:723-731.

47. Goodman WG. Medical management of secondary hyperparathyroidism in chronic renal failure. Nephrol Dial Transplant 2003;18(Suppl. 3):iii2-8.

48. Drüeke TB. Renal osteodystrophy: management of hyperphosphataemia. NephrolDial Transplant2000;15/Suppl. 5):32-33.

49. Fukagawa M, Kazama JJ, Kurokawa K. Renal osteodystrophy and secondary hyperparathyroidism. Nephrol Dial Transplant 2002;17(Suppl. 10):2-5.

50. Weinreich T. Prevention of renal osteodystrophy in peritoneal dialysis. Kidney Int 1998;54:2226-2233.

51. Hörl WH. The clinical consequences of secondary hyperparathyroidism: focus on clinical outcomes. Nephrol
Dial Transplant 2004;19(Suppl. 5):V2-8.

52. Guérin AP, London GM, Marchais SJ, Metivier F. Arterial stiffening and vascular calcifications in end-stage renal disease. Nephrol Dial Transplant 2000;15:1014-1021. 